\title{
VISUAL PERCEPTION OF PRIMARY DISPLAY PANEL OF COFFEE PACKAGING
}

\author{
Wirania Swasty $^{1 *}$, Arry Mustikawan ${ }^{2}$, Fariha Eridani Naufalina ${ }^{3}$ \\ 1,2,3 School of Creative Industries, Telkom University, Terusan Buah Batu Bandung 40257, Indonesia \\ Email: ${ }^{1}$ wirania@ telkomuniversity.ac.id, ${ }^{2}$ arrysoe@ telkomuniversity.ac.id, ${ }^{3}$ farihaenaufalina@ gmail.com \\ ${ }^{*}$ Corresponding author
}

\begin{abstract}
Previous research only discussed the perception of color combinations for the primary display panel. This study was not only focused on color; but on other visual elements, too. This research aimed to know the primary display panel that was more desirable to consumers and uncovered the linkage between product perception and preference by using a quantitative approach. As for the method used was the case study of brand Puntang Coffee. Data collection was done by conducting literature study, redesign experiment and questionnaires, whereas data analyzed by using the ANOVA test and Turkey HSD Method. From data, it was revealed that the highest valuation of respondents of all three designs displayed was Design C; which proposed by the designer team, that was perceived better by respondents.
\end{abstract}

Keywords: Packaging; primary display panel; perception; visual.

\section{Introduction}

During this time, West Java is famous for its beautiful tea plantations. Over the last five years, coffee is becoming famous in West Java. Coffee commodities began to be manufactured and processed by farmers or local business groups. Coffee Label from West Java started to expand the market, such as Manglayang coffee, Malabar coffee, Wanoja coffee, and Murbeng Puntang Coffee (Siswadi, 2017). The name of Gunung Puntang Coffee bounced when the Indonesian coffee transaction was held in the event of Specialty Coffee Association of America (SCAA) Expo 2016 in Atlanta, Georgia, United States, 14-17 April 2016 (Setiawan, 2016). Coffee from plantation in Bandung district sold with a value of IDR 750,000 per kilogram.

The coffee cultivation of West Java began to gain momentum in 2005, along with the proliferation of coffee shops. Although the growth is promising, Minister of Trade at that time, Thomas Trikasih Lembong recognized the branding or awareness of Indonesian coffee is still less maximum. People of the world have only known some types of coffee from regions in Indonesia, such as coffee Gayo, Toraja, Mandailing (Ardhanareswari, 2016).

Therefore, it takes rebranding efforts and improves the marketing of West Java Coffee, one of which is through packaging design (Rundh, 2016) which is in line with the Ministry of Trade. Packaging is the activity of designing and producing containers or wrappers for a product. The main function of packaging is to maintain the durability and safety of delivery of food products until consumed. The second main function of packaging is marketing (Keller, 2013;
Mohebbi, 2014; Rundh, 2016). While quoted from Bassin (1988) in Kotler and Keller (2012), packaging both reviewed from two viewpoints -the company and the customer, has functions such as: (1) identifying the brand, (2) protecting the product included in the distribution requirements, (3) assisting when storage, (4) conveying descriptive and persuasive information about the products offered, and (5) increasing product consumption.

Packaging design elements such as brands, illustrations, text elements and others are organized according to the priority and principles of graphic design to be attractive and communicative packaging. The graphic design of the packaging should be able to maximize the design area provided by the design structure so that the information delivered can be loaded properly, as well as the impact of the packaging graphic design can also support the appearance of packaging when on the display or point of purchase (Wahyudi \& Satriyono, 2017). This is in line with Julianti (2014) which confirms the linkage and the close dependency between the product and the packaging. When consumers buy products they've never bought and try to use, they decide to buy a product that could simply want to try it because the packaging looks interesting. Prior research confirmed that packaging should be innovative and creative to compete with other prime manufacturer (Abidin, Effendi, Ibrahim, \& Idris, 2014).

The existing elements in the packaging design according to their use as follows:

a) Brand; the brand name that appears through the logo is one of the most important elements on a product packaging. Brand differentiates a product with competitor products (Grundey, 2010). 
b) Colors are believed to be the most easily visible design elements of the human eye. In its use this color affects the consumer's perception of its products (Seher, Arshad, Ellahi, \& Shahid, 2012; Mohebbi, 2014; Yu et al., 2018). The effective colors for packaging can communicate the message that company want to deliver (Seher et al., 2012).

c) The text in the packaging design appears in many forms; starting from brand name (brand), sub brand, product description (descriptor) variant name, benefit use, support claims (reason to believe), romantic text (marketing claim), composition information, net weight and adequacy rate of nutrients (for food products packaging). The use of text strategy involves selecting a font (Beyon \& Cox-Boyd, 2020), spacing between the letters (kerning), spacing between lines (leading), thin thickness or the font (type style), etc.

d) Image; is a graphical illustration, whether it is created manually or digitally, it can also be a photo illustration. Using illustrations or photographs can help to make packaging designs more attractive, simpler and more convincing (Wahyudi \& Satriyono, 2017). According Amsterbrand (a research institutions in the Netherlands) as cited from Gumulya and Onggo (2016), image arouse automatic feelings and conclusion seen from the packaging, even if the image is not associated with the product.

In addition to fulfill the functional aspects, the packaging should also pay attention to the aesthetic aspect, both in its shape, size, color, materials and other graphical elements (Ruumpol, 2014; Swasty, 2016; Velasco, Salgado-Montejo, Marmolejo-Ramos, \& Spence, 2014). Thus, West Java Coffee products are hoped to expand the market by successfully en-tering the retail in modern markets and souvenirs outlets at the international airport. Moreover, modern retail developments recently make business competition increasingly strict (Arifianti, 2016). An estimated 73 percents of purchase decisions were made at the point of sale. In packaging scan at point of sale, perception is important for decision making process (Rettie \& Brewer, 2000).

Prior research conducted by Letona, Chacon, Roberto, and Barnoya (2014) was designed to get better understanding on the most frequently purchased snack foods by children and whether their product perceptions were influenced by the food packaging. Another scholar studied whether the packaging have an impact on consumers' minds and analyze their purchasing capacity as well (Singh, 2018).
A study by Velasco et al. (2014) designed on shapes were reported to provide information about the taste of a product. And the results pointed out that rounded shapes express the "sweet" tastes while angular shapes convey "sour tastes". Whereas The study conducted by Apsari (2012) examined the font size of the brand, the shape and color of the shampoo bottle. The combination of these three factors is considered as the most interesting and therefore tested using Conjoint Analysis and eye-tracking methods. From this research, it was found that the colored thin bottle with large brand font size attracted the most attention of consumers.

Another study done by Gumulya and Onggo (2016) examine consumer perceptions of cosmetic product packaging by using semantic theory approach, whether the existing packaging has effectively conveyed the benefits of the product. Selected brands are four well-known brands from major cosmetics companies in Indonesia. From the study, it revealed that every visual element in the package, which is the picture, material, color, size and shape can influence consumers' perceptions about the benefits of the product.

Previous research (Swasty, Gunawan, Koesoemadinata, \& Putri, 2018; Wei, Ou, \& Luo, 2008; Wei, Ou, Luo, \& Hutchings, 2014) discuss only the perception of color combinations on the primary display panel of food products, i.e. banana chips and fruit juice. This study of visual perception is not only focused on colour but also on other packaging visual elements such as brand (logo), text (information), and image (illustration). However, this study is limited to the graphic design of the primary display panel of coffee home industry. The study also focuses on a Small Medium Enterprise product. To the best of our knowledge, less literature addressed SMEs, most of them studied on large company brands. In addition, management of SME is different compared with the larger companies (Centeno, Hart, \& Dinnie, 2013).

According to Setiawan, Riyanto, and Yuwono (2013), the packaging for SME food products has only been plastic with labels or stickers that contain information about the product. With such packaging, the product has less value and certainly does not attract much interest from consumers. So, their study addressed design for SME product packaging that has a more attracttive design, to increase the selling value of the product.

Packaging research and the basic theory of visual attention regarding the decision making process are detailed in articles compiled by Clement (2007). This article presents the advantages of the human behaviour 
model for in-store purchase and conducted through eye tracking experiment methods to explain how the visual design of packaging affects the buying behaviour and explains the stages in the decision-making process. That study also demonstrates a decision making process where visual attention at the point of sale is a main factor for the post-purchase stage.

Therefore, the research problem formulation of this study as follows: (1) which design of the primary display panel (PDP) of packaging is more desirable to consumers (the existing one, the desired design by business owner, or the design proposed by the designer team)? (2) How is the relation between product perception and preference?

The purpose of this study is to know the primary display panel design of packaging that is more desirable to consumers and uncover the linkage between product perception and preference. The hypothesis of this research is as follows:

$H a=$ There is a significant difference between group of price perception and quality in the primary display panel experiment of coffee packaging.

$H o=$ There is no significant difference between group of price perception and quality in the primary display panel experiment of coffee packaging.

\section{Methods}

This research uses exploratory research with a quantitative approach. The method used is the case study of Sundanese coffee of a Small Medium Enterprise (SME) in Bandung Regency namely Puntang Coffee brand. SME is adopted as a case study because the contributing of SME to the Gross Domestic Product/GDP has extensive acrooss different nation (Centeno et al., 2013; Abidin et al., 2014).

Data collection was done in several phases. The first phase was the literature study from textbooks, academic journals and similar research. The second phase began with creating a redesign experiment of primary display panel of coffee packaging. Redesign was done twice; the first redesign was based on the owners of the SME's and the second was the redesign proposed by the graphic designer team. The results of this redesign are used as one of the questionnaire questions to reveal product perception and preference.

After redesigning the primary display panel of coffee packaging was completed, questionnaires relating to the research objectives began to be compiled. Questions to uncover respondents' perception of the graphic element of the primary display panel packaging using the semantic method of 1-9 scale. Respondents were shown three packaging designs to be assessed based on their respective perceptions, ranging from logos, information, illustrations, color combinations, interest to products, trial intention, purchase intention, to the perception of quality and price of each of the primary display panel design. Subsequent questionnaires were disseminated online using Google forms. From this questionnaire, it is expected to answer the issue of this research problem.

The last step was to process the collected data and analyze the data by comparing the existing packaging design theories. Data is then processed using the ANOVA (Analysis of Variance) test to examine changes during three design experiments. This phase was ended with the withdrawal of conclusions. The overall research phase shown in the following Figure 1.

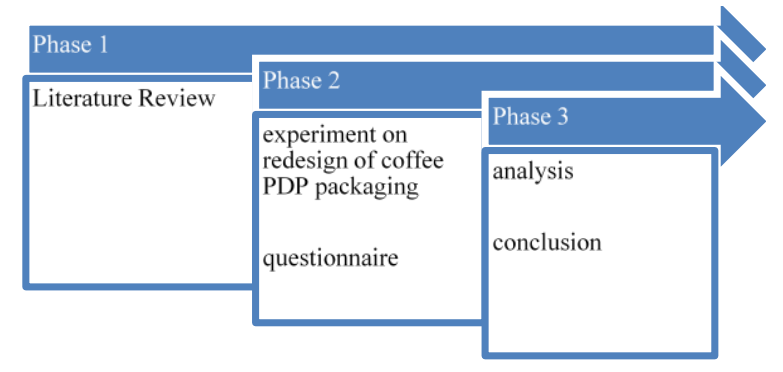

Figure 1. Phases of research

\section{Result and Discussion}

Design A is the existing design of the brand Puntang Coffee used today (as this paper written). Design $\mathrm{B}$ is a redesign which is a request packaging design from the owner of Puntang Coffee. Design C is a design proposed by a team of researchers who have graphic design backgrounds.

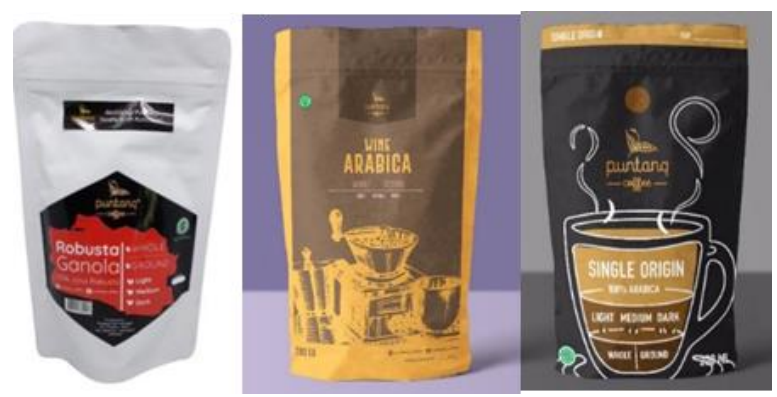

Figure 2. (From left to right) a. existing primary display panel packaging, b. requested design by owner, c. design by graphic designer.

Respondents participated are as many as 105 people. The following Table 1 is the respondents' profile that participate in the questionnaires. The age of respondents ranged between 19-57 years with an average age of 32 years and the most respondents' age of 23 years. 
Table 1

\section{Respondents' Profile}

\begin{tabular}{lcc}
\hline Respondents profile & Total & Frequency \\
\hline Gender & 56 & 53 \\
Men & 49 & 47 \\
Women & & \\
Occupancy & 18 & 17 \\
Students & 69 & 66 \\
Employees & 12 & 12 \\
Entrepreneurs & 6 & 5 \\
Others & & \\
Revenue & 5 & 4 \\
Less than IDR 600.000 & 19 & 18 \\
IDR 600.000-1.000.000 & 8 & 7 \\
IDR 1.000.000-1.800.000 & 24 & 23 \\
IDR 1.800.000-3.000.000 & 49 & 48 \\
More than IDR 3.000.000 & & \\
\hline
\end{tabular}

From the disseminating questionnaires, it was revealed that the form of packaging was the most interesting factor of a package in a supermarket shelf. While the graphical element in the primary display panel that draws attention to the respondent is the illustration on the packaging followed by the color of the packaging. A total of $44 \%$ of respondents distinguish the packaging of a similar product in a shelf rack by looking at the illustration on the primary display panel. There are only a small portion (27\% of respondents) who see the logo/brand when distinguishing the packaging of a similar product. It is further emphasized by the statement that most respondents (as many as $48 \%$ of respondents) reveal the reasons for deciding the product's purchase based on the image/photo illustration.

The questions in the questionnaire would like to uncover the graphical elements of the primary display panel of each package design (A, B, and C). As for the variables for logos and information is unclear and clear; Variables for image/photo illustrations and color combinations are bad and good. The variables for quality are bad and good; as well as variables for prices are inexpensive and expensive. Respondents were also asked for the purpose of whether the product was interesting, whether intend to try the product and want to buy the product by looking the primary display panel shown.

Data was processed by ANOVA test to find out which of the primary display panel design of all three designs are perceived best and interesting according to the respondents' perception (Table 2). Furthermore, a test of homogeneity of variances was conducted. Based on Table 3, it can be seen that the value of Sig 0.080 . Because the value of Sig is greater than 0.05 , it can be concluded that the population variant is homogeneous so that it can be tested one-way ANOVA.

Table 3

Test of Homogeneity of Variances

\begin{tabular}{cccc}
\hline \multicolumn{4}{c}{ Design } \\
\hline Levene Statistic & $d f 1$ & $d f 2$ & Sig. \\
2.540 & 2 & 312 & .080 \\
\hline
\end{tabular}

Based on ANOVA test results on the choice of respondents from all three designs are known if $F_{\text {counts }}$ by 80.195 (Table 4 ). This will be compared to the $F_{\text {table }}$ to test the hypothesis. The hypotheses in this case are as follows:

If $F_{\text {counts }}>F t_{a b l e}$ then $H_{o}$ is rejected and means it has a significant difference

If $F_{\text {counts }}<f_{\text {table }}$ then $H_{o}$ is rejected and means it has no significant difference.

Based on the calculation result (Table 4) then obtained $F_{\text {table }}$ for the total Sig 0.05 value with the sample 105 then obtained $F_{\text {table }}$ of 3.933. With this result then the $F_{\text {count }} 80.195>F_{\text {table }} 3.933$. This means that $H o$ is rejected or there is a significant difference between design options A, B, C. Next post hoc test was held to know which groups are choosing $\mathrm{A}, \mathrm{B}$, and $\mathrm{C}$ designs.

Table 2

Choices Between Design A, B, and C

Descriptive

\begin{tabular}{|c|c|c|c|c|c|c|c|c|}
\hline \multicolumn{9}{|c|}{ Design } \\
\hline & \multirow[b]{2}{*}{$N$} & \multirow{2}{*}{ Mean } & \multirow{2}{*}{$\begin{array}{c}\text { Std. } \\
\text { Deviation }\end{array}$} & \multirow{2}{*}{$\begin{array}{l}\text { Std. } \\
\text { Error }\end{array}$} & \multicolumn{2}{|c|}{$\begin{array}{l}\text { 95\% Confidence Interval for } \\
\text { Mean }\end{array}$} & \multirow{2}{*}{ Minimum } & \multirow{2}{*}{ Maximum } \\
\hline & & & & & $\begin{array}{l}\text { Lower } \\
\text { Bound }\end{array}$ & $\begin{array}{l}\text { Upper } \\
\text { Bound }\end{array}$ & & \\
\hline A & 105 & 42.99 & 13.763 & 1.343 & 40.33 & 45.65 & 10 & 74 \\
\hline B & 105 & 58.75 & 11.179 & 1.091 & 56.59 & 60.92 & 12 & 81 \\
\hline $\mathrm{C}$ & 105 & 63.66 & 11.983 & 1.169 & 61.34 & 65.98 & 23 & 81 \\
\hline Total & 105 & 55.13 & 15.155 & .854 & 53.45 & 56.81 & 10 & 81 \\
\hline
\end{tabular}


Table 4

ANOVA

\begin{tabular}{lcrrrr}
\hline \multicolumn{1}{c}{ Design } & Sum of Squares & \multicolumn{1}{c}{$d f$} & Mean Square & $F$ & Sig. \\
\hline Between Groups & 24486.190 & 2 & 12243.095 & 80.195 & .000 \\
Within Groups & 47632.210 & 312 & 152.667 & & \\
Total & 72118.400 & 314 & & & \\
\hline
\end{tabular}

Table 5

Multiple Comparisons

\begin{tabular}{ccccccr}
\hline \multicolumn{7}{c}{ Dependent Variable: DESIGN } \\
\hline \multirow{2}{*}{ (I) choice } & (J) Choice & $\begin{array}{c}\text { Mean Difference } \\
(\mathrm{I}-\mathrm{J})\end{array}$ & Std. Error & Sig. & \multicolumn{2}{c}{ 95\% Confidence Interval } \\
\cline { 6 - 7 } Design A & Design B & $-15.762^{*}$ & 1.705 & .000 & -19.78 & -11.75 \\
& Design C & $-20.667^{*}$ & 1.705 & .000 & -24.68 & -16.65 \\
Design B & Design A & $15.762^{*}$ & 1.705 & .000 & 11.75 & 19.78 \\
& Design C & $-4.905^{*}$ & 1.705 & .012 & -8.92 & -.89 \\
Design C & Design A & $20.667^{*}$ & 1.705 & .000 & 16.65 & 24.68 \\
& Design B & $4.905^{*}$ & 1.705 & .012 & .89 & 8.92 \\
\hline
\end{tabular}

*. The mean difference is significant at the 0.05 level.

Based on the SPSS test result with the Tukey HSD method (Table 5), there can be a group difference in design options. It can be seen in the mean difference column there is a sign $(*)$ which means there is a noticeable or significant difference. If there is no sign (*) then the difference is not significant.

Table 6

Tukey HSD Test

\begin{tabular}{ccccc}
\hline \multicolumn{5}{c}{ Tukey HSD } \\
\hline \multirow{2}{*}{ Choices } & \multirow{2}{*}{$N$} & \multicolumn{3}{c}{ Subset for alpha $=0.05$} \\
\cline { 3 - 5 } & & 1 & 2 & 3 \\
A & 105 & 42.99 & & \\
B & 105 & & 58.75 & \\
C & 105 & & & 63.66 \\
Sig. & & 1.000 & 1.000 & 1.000 \\
\hline
\end{tabular}

Means for groups in homogeneous subsets are displayed. a. Uses Harmonic Mean Sample Size $=105.000$.

From data in Table 6, it is revealed that the respondents' assessment of the three designs displayed is Design A has the lowest value of 42.99 and the highest option is Design C of 63.66. It is assumed that the highest-value choice has the meaning that the design consisting of logo placement, information clarity, illustration selection and color combinations are perceived better by respondents.

Furthermore, the questionnaire results about interest in the product, intend to try the product and to buy the products processed using the same method. From the questionnaire it was revealed that design B and design $\mathrm{C}$ had no significant difference to the respondents' intention to buy the product. Similarly, when asked about quality and price. From the questionnaire, it was revealed that design $\mathrm{B}$ and design $\mathrm{C}$ had no significant difference to perception of quality and price perception.

Design $\mathrm{B}$ and Design $\mathrm{C}$ have a big image which relates to coffee. Design $B$ has an image of coffee machine that shows to the variant of coffee itself, while Design $C$ has an image of a cup of coffee which shows the ingridients of variant of coffee itself. Moreover, Design B and Design C use brown colour that reflects the product which is coffee. This study suggest that respondents more prefer the design which has a big and attractive image and informative colour and it is perceived better by respondent, both quality and price. This result is aligned with the earlier study by Gumulya and Onggo (2016), that image arouse automatic feelings and conclusion seen from the packaging. Furthermore, every visual element in the package, especially image and colour in this case can influence consumers' perceptions about the benefits of the product Gumulya and Onggo (2016), and catch visual attention Clement (2007). In this study, the designer team has been understood what message to convey and know the exact visual elements to convey the message as Gumulya and Onggo (2016) address in their study.

\section{Conclusion}

This study wants to sudy and compare existing designs, which are desirable by SME owner, and which are proposed by the graphic designer team. From data, it is revealed that 105 respondents tend to be more interested in design C. Design C is likely to be 
assessed well due to the delivery of information to prospective consumers about the logo, clear product information, quality, price meet the good packaging label design requirements. In addition, design $\mathrm{C}$ emphasizes hierarchical information and readability.

It was also concluded that design $\mathrm{C}$ was able to display the brand identity and key communication elements which are important areas in aspects of visual communication and marketing strategies; as showed through graphics and communication elements in primary display panel which is regarded by Mohebbi (2014) as a main success. This is pointed out by earlier study that product manager as well as designers should capitalize on this fact to build brand perception (Velasco et al., 2014). Furthermore, this study is expected that the owner/brand managers of SME can experiment based on creativity and willingness to learn (Centeno et al., 2013). Good packaging design is the most important promotional tool for a product that has many competitors (Setiawan et al., 2013) such as coffee. Thus, when a product is displayed in supermarket for instance, it will get attention first than other products.

The designer needs to understand what message to convey and know the exact visual elements to convey the message (Gumulya \& Onggo, 2016). Design $C$ is a design made by a team of researchers who have graphic design background. As such, the design already considers consumer behavior and purchasing decisions. This was reinforced by a questionnaire asking whether the respondent would buy the product.

This research is only limited to the primary display panel of coffee product packaging. Future research should discuss about the perception of packaging thoroughly from the packaging structure and packaging surface (the primary display panel as well). Further research should evaluate packaging of some SME's food and beverages products not only coffee product.

\section{References}

Abidin, S. Z., Effendi, R. A. A. R. A., Ibrahim, R., \& Idris, M. Z. (2014). A semantic approach in perception for packaging in the sme's food industries in Malaysia: A case study of Malaysia food product branding in United Kingdom. Procedia - Social and Behavioral Sciences, 115, 115-130.

Apsari, S. (2012). Analisis kombinasi faktor pada packaging produk shampoo dengan menggunakan metode eye-tracking. Undergraduate Thesis, Universitas Indonesia, Jakarta.
Ardhanareswari, A. (2016). Ekspor kopi RI diprediksi tumbuh hingga 15\%. Retrieved April 12, 2019, from https://ekonomi.bisnis.com/read/20160409/ 12/536282/2016-ekspor-kopi-ri-diprediksi-tumbuh-hingga -15.

Arifianti, R. (2016). Analisis tata letak dalam perspektif ritel. Adbispreneur, 1(3), 251-258.

Beyon, J., \& Cox-Boyd, C. (2020). The influence of font type and color on online information recall. North American Journal of Psychology, 22(1), 13-26.

Centeno, E., Hart, S., \& Dinnie, K. (2013). The five phases of sme brand-building. Journal of Brand Management, 20(6), 445-457.

Clement, J. (2007). Visual influence on in-store buying decisions: An eye-track experiment on the visual influence of packaging design. Journal of Marketing Management, 23(9-10), 917-928.

Grundey, D. (2010). Functionality of product packaging: Surveying consumers' attitude towards selected cosmetic brands. Economics and Sociology, 3(1), 87-103.

Gumulya, D., \& Onggo, T. A. (2016). Penelitian persepsi kemasan produk skin care wanita dengan pendekatan teori semantik. Journal of Visual Art and Design, 8(2), 119-152.

Julianti, S. (2014). The art of packaging: Mengenal metode, teknik, \& strategi. Jakarta: Gramedia.

Keller, K. L. (2013). Strategic brand management: Building, measuring, and managing brand equity. Global Edition. $4^{\text {th }}$ Ed. Harlow, UK: Pearson Education Limited.

Kotler, P., \& Keller, K. L. (2012). Marketing management. $14^{\text {th }}$ Ed Global. New Jersey, NJ: Pearson Education.

Letona, P., Chacon, V., Roberto, C. \& Barnoya, J. (2014). A qualitative study of children's snack food packaging perceptions and preferences. BMC Public Health, 14(1), 1-6.

Mohebbi, B. (2014). The art of packaging: An investigation into the role of color in packaging, marketing, and branding. International Journal of Organizational Leadership, 3(2), 92-102.

Rettie, R., \& Brewer, C. (2000). The verbal and visual components of package design. Journal of Product \& Brand Management, 9(1), 56-70.

Rundh, B. (2016). The role of packaging within marketing and value creation. British Food Journal, 118(10), 2491-2511.

Ruumpol, I. (2014). In the eye of the consumer: The influence of package shape and package color on perceived product healthfulness. Master Thesis, Communication Studies, Enschede. 
Seher, T., Arshad, M., Ellahi, S. \& Shahid, M. (2012). Impact of colors on advertisement and packaging on buying behavior. Management Science Letters, 2(6), 2085-2096.

Setiawan, B. M. (2016). Dari Puntang menjangkau dunia. Retrieved April 12, 2019, from http://media indonesia.com/read/detail/50943-suryomentarampemikir-psikologi-modern-indonesia.

Setiawan, J., Riyanto, B. \& Yuwono, E. C. (2013). Perancangan desain kemasan camilan tradisional marning jagung produksi Soleh Malang. Jurnal DKV Adiwarna, 1(2), 1-11.

Singh, R. K. (2018). The effect of packaging attributes on consumer perception. International Journal for Innovative Research in Multidisciplinary Field, 4(5), 340-346.

Siswadi, A. (2017). Semerbak Tatar Sunda Coffee. Retrieved April 12, 2019, from https://beritagar. $\mathrm{id} /$ artikel/laporankhas/semerbak-kopi-tatar-sunda.

Swasty, W. (2016). Branding:Memahami dan merancang strategi merek. Bandung: Rosda.

Swasty, W., Gunawan, A. N. S., Koesoemadinata, M. I. P., \& Putri, M. K. (2018). How colour perceived and the relation between colour percep- tions and product preferences. A study case of banana chips packaging design. A paper presented in conference Bandung Creative Movement, Bandung, Indonesia.

Velasco, C., Salgado-Montejo, A., Marmolejo-Ramos, F., \& Spence, C. (2014). Predictive packaging design: Tasting shapes, typefaces, names, and sounds. Food Quality and Preference, 34(June), 88-95.

Wahyudi, N., \& Satriyono, S. (2017). Mantra kemasan juara. Jakarta: Elex Media Komputindo.

Wei, S. T., Ou, L. C., \& Luo, M. R. (2008). Colour design for carton-packed fruit juice packages. in Undisciplined! Design Research Society Conference 2008. Sheffield, UK: Sheffield Hallam University, 1-13.

Wei, S. T., Ou, L. C., Luo, M. R., \& Hutchings, J. B. (2014). Package design: Colour harmony and consumer expectations. International Journal of Design, 8(1), 109-126.

Yu, L., Westland, S., Li, Z., Pan, Q., Shin, M. J. \& Won, S. (2018). The role of individual colour preferences in consumer purchase decisions. Color Research and Application, 43(2), 258-267. 